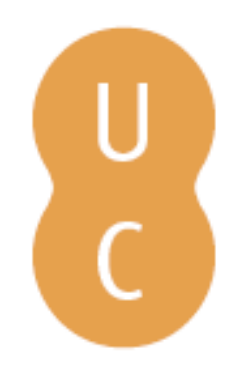

\title{
nombalina
}

\section{A "barbarian" symposium and the absence of philanth ropia (Artaxerxes 15)}

\author{
Autor(es): Almagor, Eran
}

Publicado por: Imprensa da Universidade de Coimbra; Centro de Estudos Clássicos e

URL

persistente: URI:http://hdl.handle.net/10316.2/31987

DOI: $\quad$ DOI:http://dx.doi.org/10.14195/978-989-8281-17-3_13

Accessed : $\quad$ 26-Apr-2023 11:25:42

A navegação consulta e descarregamento dos títulos inseridos nas Bibliotecas Digitais UC Digitalis, UC Pombalina e UC Impactum, pressupõem a aceitação plena e sem reservas dos Termos e Condições de Uso destas Bibliotecas Digitais, disponíveis em https://digitalis.uc.pt/pt-pt/termos.

Conforme exposto nos referidos Termos e Condições de Uso, o descarregamento de títulos de acesso restrito requer uma licença válida de autorização devendo o utilizador aceder ao(s) documento(s) a partir de um endereço de IP da instituição detentora da supramencionada licença.

Ao utilizador é apenas permitido o descarregamento para uso pessoal, pelo que o emprego do(s) título(s) descarregado(s) para outro fim, designadamente comercial, carece de autorização do respetivo autor ou editor da obra.

Na medida em que todas as obras da UC Digitalis se encontram protegidas pelo Código do Direito de Autor e Direitos Conexos e demais legislação aplicável, toda a cópia, parcial ou total, deste documento, nos casos em que é legalmente admitida, deverá conter ou fazer-se acompanhar por este aviso.

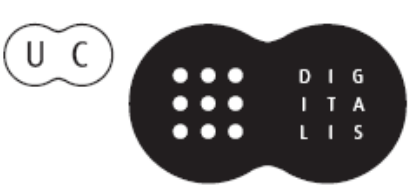




\section{Symposion and Philanthropia in Plutarch}

\section{José Ribeiro Ferreira, Delfim Leão Manuel Troster e Paula Barata Dias (eds.)}

IMPRENSA DA UNIVERSIDADE DE COIMBRA 


\title{
A “BARBARIAN” SYMPOSIUM AND THE ABSENCE OF PHILANTHROPIA (ARTAXERXES 15)*
}

\author{
Eran Almagor \\ The Hebrew University of Jerusalem
}

\begin{abstract}
This paper studies a unique symposium scene in the Artaxerxes and aims to understand its narratological significance in the biography. It is a "barbarian" banquet, which in many respects is the complete opposite of its Greek counterpart. Yet familiar features of the symposium are nevertheless discernible in it. During the feast, Mithridates, an inebriated Persian, is tricked into telling a certain truth, which contradicts the official royal version. As a result he is brutally punished by Artaxerxes, in a deed that essentially removes the trait of philanthropia from the monarch. The paper presents how, on the one hand, the wine imbibed at the party can be regarded as revealing the true character of the king, and how, on the other, the symposium is crucial in altering the ethos of Artaxerxes. Like Mithridates at the banquet, the reader is also baffled by the interplay of ethnic stereotypes, and by the thin line between the real and the apparent, artistically presented by Plutarch.
\end{abstract}

The Greek Symposium, according to Plutarch, should produce Philanthropia and friendly feeling among its participants ${ }^{1}$. By contrast, in a non-Greek setting found in the biography of Artaxerxes (15.1-7), a "barbarian" symposium, as it were, is portrayed by Plutarch as leading to the effective removal of the trait of Philanthropia from the Persian king. It is the aim of this paper to show the manner in which this reverse outcome is created, and to demonstrate the narratological significance of the Greek symposium in this Life ${ }^{2}$.

The context is a feast taking place in the aftermath of the battle of Cunaxa (401 BC), which saw the victory of Artaxerxes over his rebellious brother, Cyrus the Younger ${ }^{3}$. The guests in this dinner are barbarian, including a young Persian named Mithridates, who was responsible, according to one version, for striking Cyrus in the temple with his spear. ${ }^{4}$. He was not the only one who

* I am grateful to Profs. C. Pelling and D. Gera for commenting on earlier drafts of this paper.

${ }^{1}$ Quaest. conv. 1.4.3.621c, 4.Proem. 660ab; Cons. ad ux. 610a; Sept. sap. conv. 156cd, 158c. Cf. S.-T. Teodorsson, 1989, p. 102; 1999, pp. 66-9; A. G. Nikolaidis, 1999, p. 342 n.17.

${ }^{2}$ The banquet is not presented as typically Persian. In the Quaest. conv. Plutarch sometimes discusses special features of the Persian dinner, which do not specifically appear here. E.g., 1.1.613a (Persians drink and dance with their concubines rather than with their wives); $1.4 .620 \mathrm{c}$ (the ability of Cyrus the Younger to hold his wine; cf. Reg. et imp. apophth. 173e); 2.1.629e-630a (many questions posed at the Persian banquets of Cyrus the Great; cf. X., Cyr. 5.2.18 ); 7.9.714a, $\mathrm{d}$ (deliberation on issues of state over wine, a custom no less Greek than Persian; cf. Hdt. 1.133; Str. 15.3.20). A rather different approach to the text of Plutarch and to this scene in particular is presented by Binder, C., Plutarchs Vita des Artaxerxes: Ein historischer Kommentar, Berlin, 2008, 244 ("reine Fiktion")

${ }^{3}$ On this battle see J. Kromayer, 1924; J. K. Anderson, 1974, pp. 106 sqq.; P. A. Rahe, 1980; J. M. Bigwood, 1983; G. Wylie, 1992; R. B. Stevenson, 1997, pp. 84-93; P. Briant, 2002, pp. 627-30.

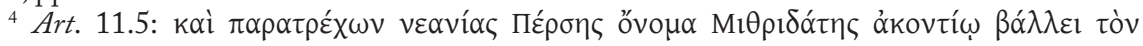


injured the prince in the course of the combat. Another person, a Carian slave from the city of Caunos, is reported to have stabbed Cyrus from behind, in the back of the leg, and the wounds inflicted by the two men brought about the death of the prince 5 . During the dinner, Mithridates relates his part in the event and instantly causes his own downfall, since the facts revealed by him contradict the official royal version. Even though Artaxerxes himself was not involved in the killing of Cyrus, as the king was quickly removed from the battle after incurring an injury (Art.11.2-3) and was not even present at the ensuing clash (Art.11.4-10,12.2,13.1), he nevertheless appropriated the glory for it. Before the feast, the king gave Mithridates gifts; but these were allegedly for another deed - namely, presenting the monarch with the blood-stained saddle-cloth of Cyrus, which had fallen from the prince's horse ${ }^{6}$.

Mithridates received the gifts silently and walked away (Art.14.7). Still, at the banquet, he is induced to disclose his feelings by Sparamizes, the chief eunuch of the queen mother, Parysatis, who wishes to avenge the death of her son Cyrus ${ }^{7}$. The ill-advised conduct of Mithridates at the dinner party leads to his brutal execution by Artaxerxes, which is detailed in the next chapter of the biography ${ }^{8}$. This scene is an adaptation of a story recounted in the Persica of Ctesias, the Greek physician at the court of the Great King ( FGrH $688 \mathrm{~F}$ 16.67) .

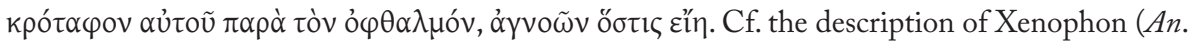

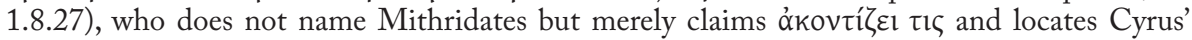
wound below the eye (úrò $\tau o ̀ v ~ o ́ \varphi \theta \alpha \lambda \mu o ́ v$ ). It is most probable that Xenophon relied on Ctesias' account. Cf. S. R. Bassett, 1999, who seems to infer too much from the minor differences between the two authors.

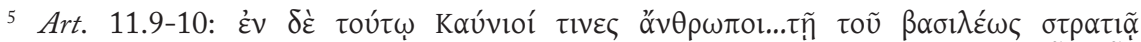

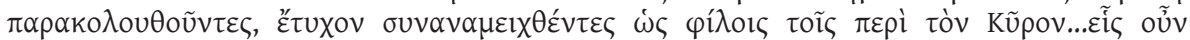

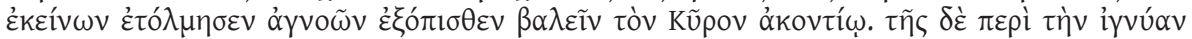

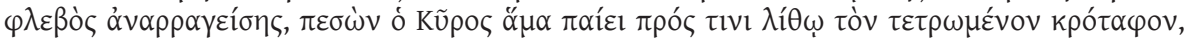

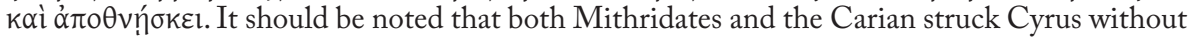
knowing his identity.

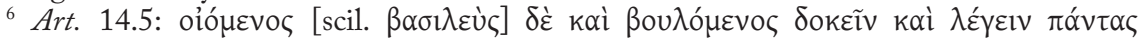

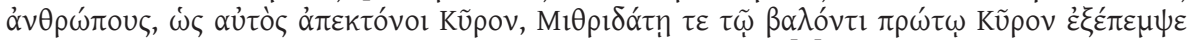

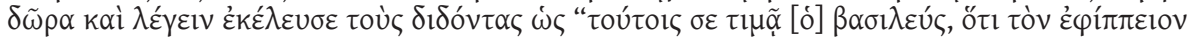

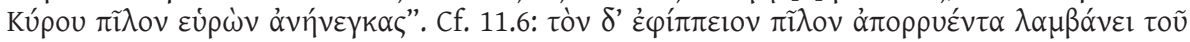

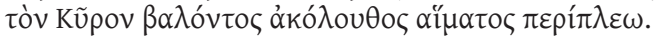

${ }^{7}$ It is possible that the whole banquet was organized by Parysatis in order to trap Mithridates, the queen mother wanting to avenge Cyrus' death by causing the noble Persian to bring harm on himself. The resigned demeanour of Mithridates upon receiving the gifts from the king had not suited her intentions, and she may have plotted to engineer his ruin. Cf. her manipulations in getting rid of other persons in Art. 17.1-8, 23.1.

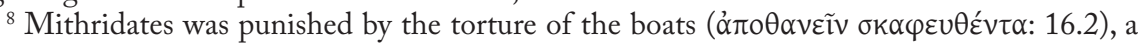
method of execution that inflicts a horrendous death. The condemned man is placed between two boats ( $\sigma \kappa \alpha ́(\varphi \alpha)$, one on top of the other, and is force-fed until he incurs severe diarrhea. While his intestinal waste accumulates in the boats, worms and other creatures breed in it and devour his flesh.

${ }_{9}^{9}$ On the Persica see F. Jасову, 1922, pp. 1640-66; R. Drews, 1973, pp. 103-16. On its shortcomings see J. M. Bigwood, 1976, 1978, 1983 (errors, questionable numbers, faulty geography, bias, simplification, confusion, duplication, anachronisms, etc.). See also R. B. 
The feast portrayed here is very different from a Greek symposium, and one could say that it is its complete opposite ${ }^{10}$. To begin with, this is not an allmale gathering ${ }^{11}$, as some of the participants are eunuchs, a problematic group in Greek imagination ${ }^{12}$, and the chief figure is a eunuch belonging to a woman, the queen mother. Nor is this an event of aristocratic and free members, since the eunuchs are slaves. Moreover, the dinner betrays no social equality among the guests, and this fact is reflected in the garments Mithridates chooses to wear to the banquet. These clothes, which were gifted to him before the banquet with the intention of exalting him above the others, are indeed admired by the rest of the company ${ }^{13}$.

The setting too is unlike that of a Greek banquet. Strictly speaking, there is no clear distinction between eating and drinking, as was customary in the Classical symposium ${ }^{14}$. In addition, drinking seems to take place before the prayer that generally accompanied the libation in the Hellenic ritual, marking the beginning of the banquet ${ }^{15}$. No entertainment is mentioned, neither music nor dance. The participants do not sing or recite ${ }^{16}$. Though there is no direct reference to drinking wine neat, in the barbarian manner, a word play on the unrestrained (akrates), intoxicated Mithridates alludes to the unmixed (akratos) wine ${ }^{17}$.

Stevenson, 1997, pp. 3-9; D. Lenfant, 2004, pp. vii-xxiv. Though lost, a short summary of the work was made in the $9^{\text {th }}$ century AD by the patriarch Photius and is included in his Bibliotheca (Codex 72). The parallel passage to Plutarch's description is extremely short: $\omega \varsigma$ 'A 'A

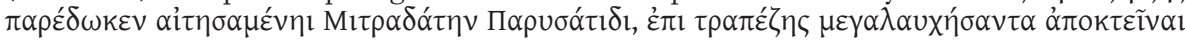

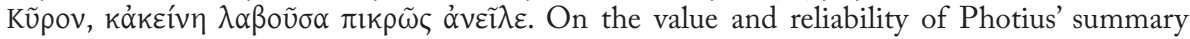
of Ctesias see G. Goossens, 1950, p. 519, J. M. Bigwood, 1976, pp. 2-5. The discrepancies between the versions of Plutarch and Photius may point to an adaptation of the original account of Ctesias by the biographer, or, alternatively, reveal that the patriarch's epitome is not accurate. There is no need to suppose that Plutarch used a different source here.

${ }^{10}$ On the actual form of the oriental symposia see W. Burkert, 1991.

${ }^{11}$ On the symposium as a drinking party intended for males only see O. Murray, 1982; 1983, p. 199; 1990, p. 6; M. J. Vickers, 1984, p. 5. The female flute players, dancing-girls (Ar., Ach. 1093, X., Smp. 2.1) and hetairas attended the symposium solely to entertain the men.

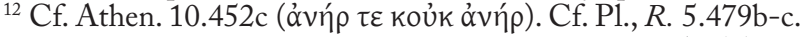

${ }^{13}$ By contrast, sympotic participants all wore wreaths (cf. Thgn. 1001; Ar., Ach.1091, 1145; Ec. 844; Menander, Pseuderacles, Fr. 451.15 Kassel-Austin; Athen. 15.669c), which not only was a ritual act signifying initiation into a new reality (see W. Rösler, 1995, p. 108) but probably also highlighted the aspect of equality and commensality. Cf. D. Tolles, 1943, pp. 28-9.

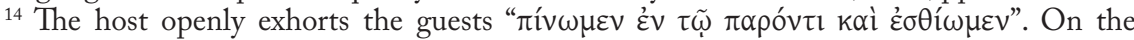
distinction between deipnon and symposium see A. Hug, 1931, pp. 1266-7; O. Murray, 1990, p. 6; 1995, p. 225. Cf. G. Paul, 1991, p. 158 on its gradual erosion in Hellenistic and Roman times.

${ }^{15}$ Cf. P1., Smp. 176a; X., An. 6.1.5; Cyr. 4.1.6; Smp. 2.1; Athen. 4.149c, e; Ar., Eq. 105. Cf. F. Lissarrague, 1990, p. 25-6. The sequence here may fit a Sassanian custom, in which a prayer for the gods and the king apparently comes after the banquet. This practice is known from a document published by J. C. Tavadia, 1935, pp. 11, 19, 89.

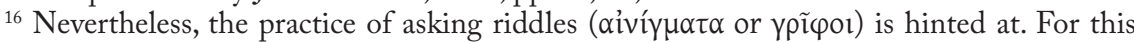
custom see Athen. 10.448b; Plut. Sept. sap. conv. 152f; Quaest. conv. 5.proem. 673ab; Ar. V.20, 1308-13; P1. Smp. 215a. Cf. Thgn., 681-2.

${ }^{17}$ An observation made by T. Duff, 1999, p. $92 \mathrm{n} .76$ with regard to the double meaning 
The banquet proceeds contrary to the code of behaviour appropriate to a symposium. There are instances of paroinia, that is, irresponsible and offensive drunkenness, insolent talk, or bybris ${ }^{18}$. No feelings of ease and joy are felt, no friendship, or euphrosyne ${ }^{19}$. There is no calm and civilized conversation, nor, for that matter, any evidence of talk flowing freely. Quite the reverse is evident; the other participants are silent upon perceiving Mithridates' calamity (Art. 15.7). Their silence is a sort of behaviour depicted by classical authors as inappropriate ${ }^{20}$. The only discourse presented in the scene - namely that between Mithridates and Sparamizes - concerns war or conflict, topics that early poets ${ }^{21}$ banned as themes unsuitable to a symposium. The dialogue is lethal. Note the mention of a knife in the first act (15.2). The very presence of weapons, in the form of the Persian akinakes, symbolizes strife in what is supposed to be a peaceful context ${ }^{22}$. All in all, the atmosphere is one of mistrust, lack of transparency and treachery. Mithridates is seduced into exposing his thoughts and harming himself, and he is isolated, as the rest of the guests let him bring about his own destruction. Though this picture supposedly describes a real party, it seems to present a thought experiment, so to speak, a suggestion of what could happen if the institution of the symposium were to fall into the hands of non-Greeks ${ }^{23}$.

It is in these barbarian circumstances that the notion of the Greek symposium is introduced, enfolded in the words of Sparamizes the eunuch on

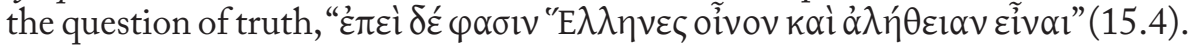

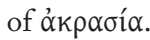

${ }^{18}$ On paroinia see X., Smp. 6.2 with B. Huss, 1999, pp. 333-4 ad loc. and S.-T. Teodorsson,

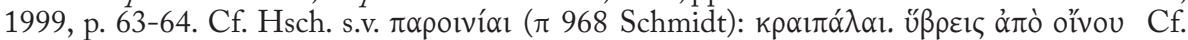
Plu., Quaest. conv. 2.10.2.644a. On avoiding bybris at dinner parties by doing "what is right"

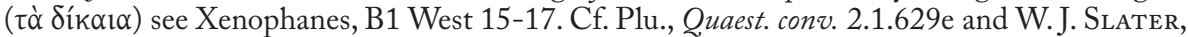
1990, pp. 214-5.

19 On euphrosyne in banquets see Anacreon, Eleg. Fr. 2 West; Cf. H. Oranje, 1984, pp. 103-7; W. J. Slater, 1990, p. 213. For examples of discordant behaviour at symposia, disrupting the ideal pleasant atmosphere, see G. Paul, 1991; F. Titchener, 1999, pp. 492-4. Cf. another banquet where things go wrong in Plut. Alex. 51.

${ }^{20}$ See X., Smp. 6.2 and B. Huss, 1999, pp. 334-5. Cf. Plu., Quaest. conv. 3.prooem. 644f.

${ }^{21}$ See Anacreon, Eleg. Fr. 2 West; Xenophanes, B1 West 21-24; cf. Thgn., 763-4. Cf. W. J. Slater, 1981.

${ }^{22}$ See W. J. Slater, 1990, pp. 215-6. Cf. the humorous allusion to Il. 2.381 (vũv $\delta$ ' है $\rho x \varepsilon \tau \alpha l$

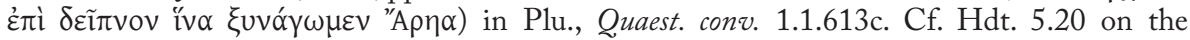
concealment of daggers in the Macedonian banquet.

${ }^{23}$ Much more than a garbled adaptation of Hellenic practices, as in Crass. 33.1-7 (on which see in this volume J. CHLUP, pp. 185-7), this scene indicates a mismatch of Greek institutions and a non-Greek context. The description fits the image of the Persians in Greek literature as not free, slaves either to the king or to their passions, and suits the portrayal of the Persian court as a scene of decadence, corruption, arbitrary decisions, hypocrisy, betrayal of trust and brutality. In accordance with the prevailing orientalist image of the Eastern Empire, men are depicted as effeminate and women as dominant. Persia is seen as a place which breeds creatures on the fringes of human society, such as eunuchs, and on the other hand blurs the distinction between a human king and divine beings. See H. Sancisi-Weerdenburg, 1987; W. Nippel, 2002, p. 290; D. L. GERA, 2007. 
This saying, connecting wine and truth, which is known from other sources ${ }^{24}$, is, according to some scholars, the very essence of the Greek symposium ${ }^{25}$. It reflects the obligation of the participants to disclose their thoughts openly and completely, as well as encapsulating the symbolic transition to a new state of existence, in which full understanding and communication are present. Yet the employment of this proverb in the present context not only evokes the Hellenic practice of the banquet but also does it in a manner considered to be a Greek way of action, one involving cunning, and an indirect scheming instead of outright savagery ${ }^{26}$.

The mention of truth entails a play on Persian religion and royal ideology. In the Zoroastrian Avesta, the world is divided between drug (the Lie, or disorder) and $a \hat{s} a$ (Truth, or cosmic, social and ritual order) ${ }^{27}$. The $d r u g$ corresponds to the evil spirit (Angra Mainyu) and the $a \hat{s} a$ is championed by the good spirit (Ahura Mazda), who will eventually prevail ${ }^{28}$. Ahura Mazda upholds Truth (Yasna 31.8), is a friend of the truthful ones or believers (aŝanan: cf. Yasna 47.5) ${ }^{29}$ and punishes liars. This belief was familiar to Greek readers - and certainly to Plutarch himself - from the portrayal of the Persians in Greek literature, with its emphasis on telling the truth as a key concept in the education of the young $^{30}$, and with the depiction of lying and dishonesty as being in Persia the most despicable of evils ${ }^{31}$. In the royal Achaemenid ideology the Lie (drauga) is considered a serious offence against the $\mathrm{king}^{32}$; it is tantamount to rebellion, as "those following the Lie" are regarded as lawbreakers ${ }^{33}$. But by persuading

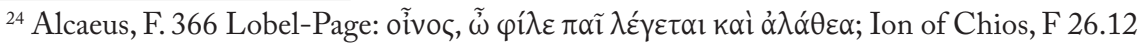
West; P1., Smp. 217e; Theoc., Idyll 29.1; Ath. 2.37f; Zenobius, Paroem. 4.5, Diogenianus, Paroem.

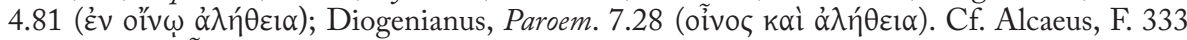

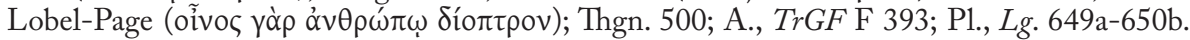
Cf. Horace, Sat. 1.4.89; Carm. 3.21.14-16; cf. Pliny, Nat. 14.141. Cf. the treatment of this view in Plu., Quaest. conv. 3. Proem. 645a-c and 7.10.715d-f.

${ }^{25}$ See W. Rösler, 1995; W. J. Henderson, 2000, p. 17.

${ }^{26}$ See M. Detienne \& J. P. Vernant, 1978.

${ }^{27} \mathrm{On}$ the centrality of this opposition between truth and lie in the Indo-Iranian religious setting prior to the emergence of the Zoroastrian belief see H. Lommel, 1930, pp. 40-52; M. Stausberg, 2002, pp. 91-5.

${ }^{28}$ Cf. Yasht 19.92-96; Cf. M. Boyce, 1975, pp. 200-1, 283; 1982, pp. 120-1. In the Gathas, the oldest stratum of the Avesta, drug appears more frequently than the evil spirit itself. See M. Boyce, 1982, p. 123.

${ }^{29} \mathrm{Cf}$. XPh. 46-56: The king demands respect for the law Ahura Mazda has established in order to be blessed (artava-). Cf. M. Boyce, 1982, pp. 174-7.

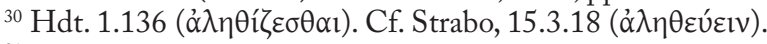

${ }^{31}$ Hdt. 1.138; cf. 7.102, 7.209. Interestingly, cf. Plu., De vit. aer. alien. 829c, who claims that they were the second worst things in Persia.

${ }^{32}$ Cf. DB 4.33-5: "Darius the King says: These are the provinces which became rebellious. The Lie made them rebellious, so that these (men) deceived the people"; cf. DB 4.36-39: "Darius the King says: You who shall be king hereafter, protect yourself vigorously from the Lie; the man who shall be a Lie-follower, him do you punish well” (trans. by R. G. Kent, 1953, p. 131). Cf. DB 1.34, 4.63; cf. DNb.12. The supposed pretenders in the Behistun text are presented as liars. cf., 1.39, 1.78, 3.80. See P. Briant, 2002, pp. 126-7, 138.

${ }^{33}$ The Liars are habitually punished in Greek depictions of Persia. See Ctesias, FGrH $688 \mathrm{~F}$

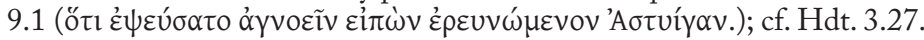


Mithridates to tell the truth about the incidents that occurred during the battle, the king's own version turns out to be a lie; Artaxerxes becomes a liar, while the truthful Mithridates is made to seem a rebel ${ }^{34}$. There is also irony in the employment of deceit to bring out the truth ${ }^{35}$. After all, it is stated clearly that Sparamizes, the eunuch of the queen mother, was not ignorant of the truth (oukk $\alpha \gamma v o \tilde{\omega} v \tau \dot{\alpha} \alpha \lambda \eta \theta \dot{\varepsilon} \varsigma:$ 15.5) but pretended to be so in order to manipulate Mithridates.

Before the feast Mithridates kept his account of the events to himself. It is the false presentation of a frank and friendly fellowship typical of a symposium that leads him to divulge everything. Mithridates seems convinced that in accordance with the Greek sympotic ethical code - apparently introduced by Sparamizes' allusion to the banquet - his vulnerable state will not be abused by any other participant at dinner and that his words will not harm him later ${ }^{36}$. He is unable to see the plot against him. Just as he missed ( $\tau o \tilde{v}$... $\partial \varphi \theta \alpha \lambda \mu$ ov

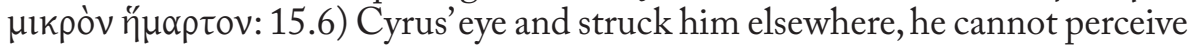
that his words about the prince's destruction in fact harm another person, namely, himself. The ploy is therefore successful. Mithridates is tricked into relating his part in slaying Cyrus, thus proving false the official version, which had Artaxerxes as the sole killer.

But the report of the events is not the only truth revealed by the unfortunate inebriated Persian. The true character of Mithridates is also disclosed through wine, and this is what Sparamizes is trying to uncover. Mithridates shows signs of excessive philotimia. Not satisfied with the rewards given him by the king, he also wishes to gain the glory of being Cyrus' killer, a title officially held by Artaxerxes. In fact, Mithridates presents himself as competing with the king, and Plutarch shows this ambition in various ways. Mithridates' arrival at the dinner wearing the clothes and jewellery he received from Artaxerxes ${ }^{37}$ alludes to a previous scene in the biography, in which Tiribazus wore the king's robe and necklace, although forbidden to do $\mathrm{so}^{38}$. The contrast made by Mithridates between idle talk about the saddle-cloth and his own actual deed $^{39}$ matches Artaxerxes' distinction between the general liberty to speak

${ }^{34}$ On the Orwellian overtones of this passage see B. Lincoln, 2007, p. 94.

${ }^{35}$ Notwithstanding n. 33, Greek authors do not hesitate to point at Persian hypocrisy, and the question of truth is often found to be the subject of ironic descriptions. For instance, according to Herodotus, the Magus' reign as king involves a deceit (3.61-3), and it also takes

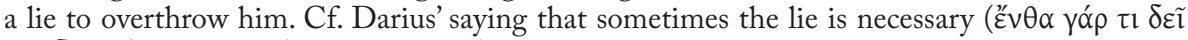

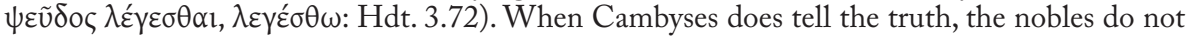
believe him (Hdt. 3.66). On deceitfulness versus truthfulness as a Leitmotiv in Herodotus' third book see S. Benardete, 1969, pp. 69-98. Cf. also Hdt. 8.142 (

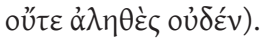

${ }^{36}$ Cf. Thgn, 309-312.

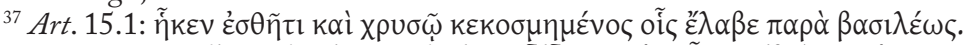

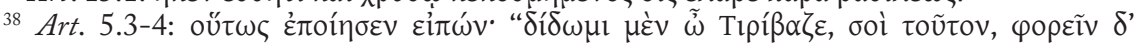

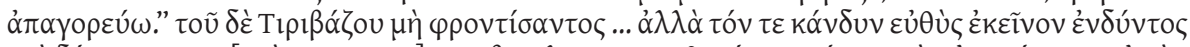

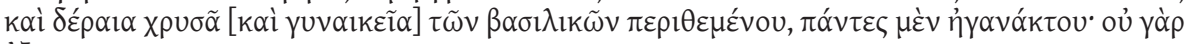
$\dot{\varepsilon} \xi \tilde{\eta} v$.

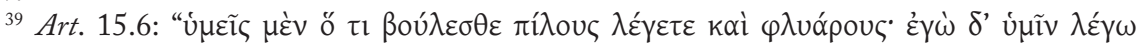


as one wishes and the monarch's unique privilege to act ${ }^{40}$. Finally, when the young Persian claims that what he did "on that day is worthy of great things" 4 , he appears to allude to Tiribazus' words of advice to the king at the scene of the battle to "remember this day, for it is unworthy of forgetfulness" 42 . What seems to be insinuated here is a war of versions between that of Artaxerxes and that of Mithridates. The young Persian gives the impression that it was he who saved the crown of Artaxerxes on that fateful day, that his acts were powerful enough to decide the feud over the monarchy, and by implication - that his power surpasses that of the king.

Upon hearing these alarming words, Artaxerxes sends Mithridates to his horrible death. This outcome causes the words of the intoxicated Persian noble to appear as conveying yet another truth, for his claim that he felled

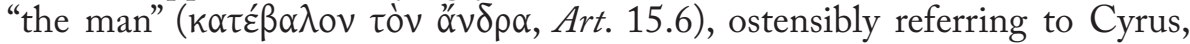
also seems to predict the downfall of Mithridates himself ${ }^{43}$. As in the battle he missed Cyrus' eye yet fatally injured the prince, now his words deliver an unintended and no less deadly blow to himself. It is the king, however, who turns this description into reality, by interpreting this utterance as disobedient and deserving of punishment. With its focus on wine and truth, the Greek symposium envisioned the human body as if it were a sort of instrument for processing liquid and transforming it into truthfulness ${ }^{44}$. Analogous to that practice, the body of Mithridates is expected to function as a similar device when he incurs the torture of the boats: into his mouth are poured fluids (milk and honey) $)^{45}$ and this punishment is meant to prove Artaxerxes' account as accurate $^{46}$. In fact, through the disintegration and complete destruction of the young Persian's body, the king establishes once and for all his version of the

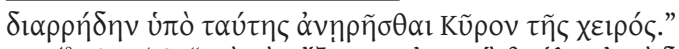

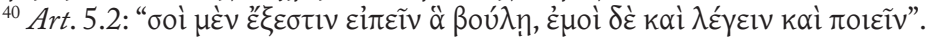

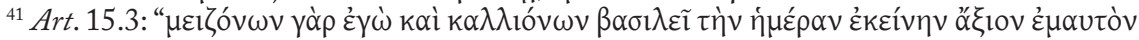
$\pi \alpha \rho \varepsilon ́ \sigma \chi \nu^{\prime \prime}$.

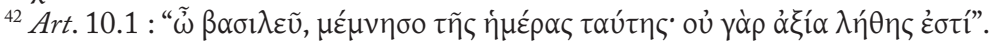

${ }^{43}$ On Dionysus giving the gift of prophecy see E., Ba. 298-301.

${ }^{44}$ P. Dubois, 1991, pp. 68, 75-91 (and passim) shows how, in the Greek mind, truth was conceived of as an inaccessible, buried secret within the body, which had to be brought to the surface, even by coercion. Presumably, one such means was liquids. Plato, Lg. 1.648a-c, $649 \mathrm{e}$ proposes that wine should be used, rather than some other test ( $\beta \alpha$ ó $\alpha \nu \circ)$ ), to reveal true facts about the character of a person. Cf. P. Dubois, 1991, pp. 108-10. Note that Diogenianus

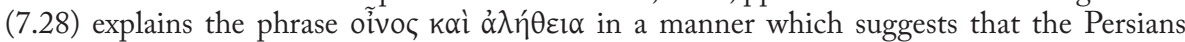
substituted tortures ( $\left.\beta \alpha \sigma_{\sigma \alpha} \alpha \nu \mathrm{l}\right)$ for wine with the aim of extracting the truth: Eü $\alpha v \delta \rho \circ \varsigma \pi \alpha \rho \alpha$

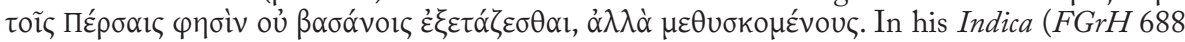
F 45.31) Ctesias describes a liquid obtained from a spring, which acts as wine; when someone

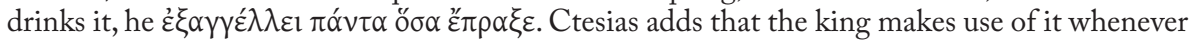
he wishes to find the truth concerning an accusation. One would assume that here again torture is being replaced by a beverage.

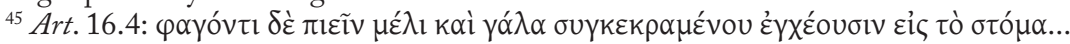

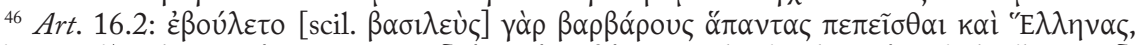

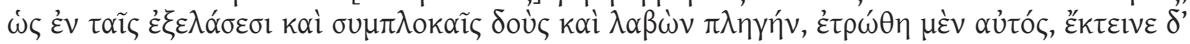

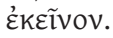


events as the 'true' one ${ }^{47}$.

This cruelty exhibited by the king is not at all what we would expect from the foregoing narrative. Earlier on (Art.4.4), he is described as one who appears $\varphi \imath \lambda \alpha ́ v \theta \rho \omega \pi \circ \zeta$ and mild. Specifically, it is stated that the king seems no less generous and kind as a recipient of favours than when he bestows favours upon others ${ }^{48}$. But here, Artaxerxes emerges as ungrateful to Mithridates, the man who struck down Cyrus and effectively handed him power. Seemingly, by his action the monarch demonstrates that the former description was false ${ }^{49}$. Up to this point in the story, the king had never tortured or sentenced anyone to death. He released Cyrus even though his brother was suspected of having attempted assassination (Art. 3.5-6); he ignored Tiribazus' insolence with respect to the royal robe and its mutinous overtones, in a way that could have only been interpreted as weakness on the king's part (Art. 5.4); towards Euclides, who admonished him publicly, he was temperate (Art. 5.2); he was relatively lenient with defectors during the war (Art.14.3-4); even the Carian who, like Mithridates, claimed the glory for Cyrus' death, was not punished by Artaxerxes himself, but was handed over to Parysatis, the queen mother (Art.14.9-10). The punishment meted out to Mithridates constitutes therefore a turning point in the revelation of the king's character. We begin to doubt whether the former Greek traits describing the barbarian monarch were accurate, especially regarding the application of the essentially Hellenic quality of $\varphi \imath \lambda \alpha v \theta \rho \omega \pi i \alpha^{50}$. Artaxerxes is now seen as a brutal, despotic oriental ruler, whose real personality is exposed by his resort to torture.

The narratological significance of the symposium is thus immediately seen. It has already been shown that wine proverbially reveals truth, but Plutarch appears to play with the idea of in uino ueritas. Here it is not merely Mithridates' own truth that his drinking reveals, but also Artaxerxes' truth. It is the wine imbibed by Mithridates that reveals the true nature of the king, the truth of what the king $i s^{51}$.

Yet this is only one way of seeing the importance of the Greek banquet in the Life and the role it plays in the characterization of the hero. Another view is possible: our symposium may not, after all, lead the way to the truth,

${ }^{47}$ According to B. Lincoln, 2007, pp. 87-94, the punishment of Mithridates was in fact a Zoroastrian "judicial ordeal", involving a careful examination of its outcome and the application of pressure in order to disclose the inner moral nature of the accused. If Mithridates was guilty, he would have to be destroyed in the process, and his physical decay would demonstrate his moral corruption.

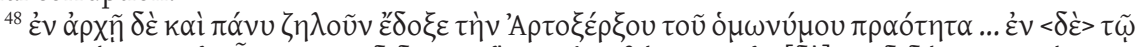

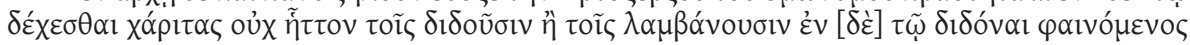

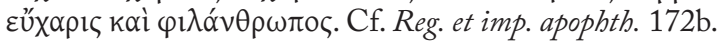

${ }^{49}$ This may also be seen in the use of the word oै $v \theta \rho \omega \pi$ o $(A r t .16 .7)$ at the end of the torture portrayal to mark the gap between the previously attributed trait and reality.

${ }^{50}$ Cf. Phil. 8.1; Flam. 5.7; Lys. 27.7; Pyrrh. 1.4. See H. M. Martin Jr., 1961, pp. 166-8, 174; Cf. R. Hirzel, 1912, p. 25; J. De Romilly, 1979, pp. 279, 303-4; A. G. Nikolaidis, 1986, pp. 239-40.

51 This notion is an expansion of the idea that wine discloses the true character of the drinker, on which see T. Duff, 1999, pp. 15 n. 6, 32 n. 56. 
but rather deviate from it, creating a new reality altogether. Plutarch seems to take great pains in creating the strong impression that truth is absent from the description of the "barbarian" feast. He does it with the help of an array of literary devices. Sparamizes is explicitly presented as deceiving his fellow drinker (15.5). The act of casting their eyes downward attributed to the guests ( vision of people who shy away from true reality ${ }^{53}$. Even the young Persian's story is only partially true, since, as will be recalled, Cyrus died as a result of injuries inflicted by two men, a Carian as well as Mithridates. Leaving the Carian out of the account is not telling the whole truth. Moreover, in the last two parts of the dialogue between Sparamizes and Mithridates the king himself is omitted: First, he is not mentioned as the recipient of the saddlecloth $^{54}$; second, he is neglected in the report of the battle (Art.15.6). Contrary to the picture given earlier, in which Artaxerxes did try to aim a blow at his brother before being wounded himself $f^{55}$, here mention is made only of the attempt by the commander of the Cadusians, Artagerses, to strike Cyrus (Art. 9.3 $)^{56}$. The struggle of the brothers and their entourages (Art.11.1-2) is skipped over. These are clear cases where aletheia gives way to lethe $e^{57}$. Noteworthy also is the absence of truthfulness indicated by the imagery of failure to hit the mark, which is prominent in the speech of Mithridates (Art.15.6), since truth signifies correspondence with reality, like a spear hitting the target, not missing $i^{58}$. To the same effect is perhaps the recurring motif of utterances that miss a real correspondence in the closing picture of the scene (15.7: $\lambda$ óyous $\delta \dot{\varepsilon}$

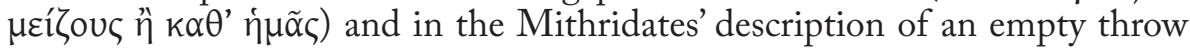

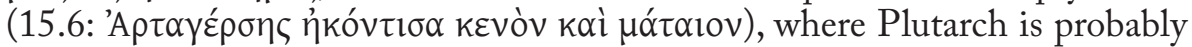
alluding to Demosthenes' idiom in the second Olynthiac oration (12) about words being vacuous and vain if unaccompanied by deeds $s^{59}$.

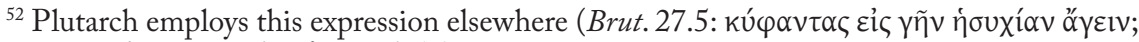

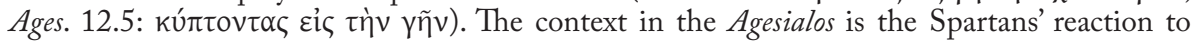
the complaints of Pharnabazus on the destruction done by them to his land. In this case, the biographer's intervention in the text can be ascertained by a comparison of this description with its probable source, X., HG. 4.1.34. Cf. D. H. Shipley, 1997, pp. 184-5.

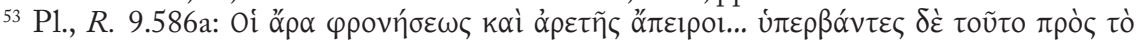

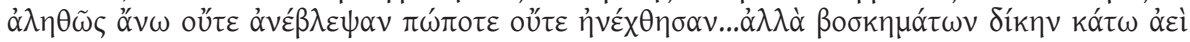

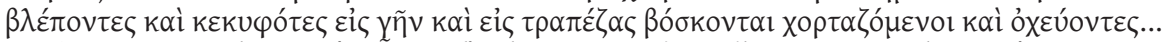

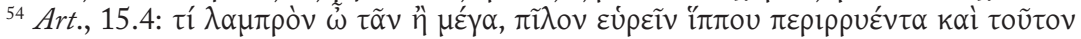

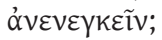

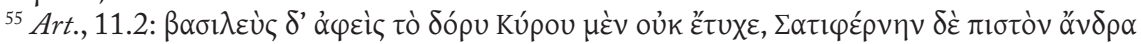

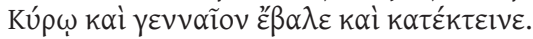

${ }^{56}$ Cf. X., An. 1.8 .24

${ }^{57} \mathrm{On}$ the ancient understanding of truth as something that is perceived or transmitted without any gaps caused by forgetfulness, neglect or ignorance, that is, complete and with no omissions, see B. SNell, 1975; T. Cole, 1983.

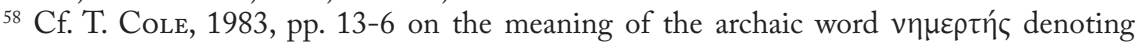
Truth, as something not failing to strike the target. Vide supra, on the correspondence between Mithridates' missing the mark in battle and his failure to grasp the situation at the symposium.

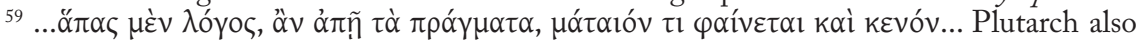
uses this phrase in the Philop. 9.7; Quom. adolesc. 28b. 
What the 'barbarian' symposium lacks in truthfulness, it gains in passion. Traditionally, the unrepressed barbarian, especially Scythian, consumption of wine was conceived of as the counterpart of the Greek banquet ${ }^{60}$. It was set as a sort of limit, one not to be transgressed by members of the civilized community ${ }^{61}$. However, in the reverse world depicted here by Plutarch, it is the Greek way of drinking that is presented both as a model to be followed by the barbarians and as having no restraints. Mithridates is encouraged to abandon his self-control and act "as the Greeks do". Ironically, while it was usually the Greeks who regarded the barbarians as uninhibited and unconstrained in their demeanour ${ }^{62}$, here it is the other way around: the Hellenes are seen as basically licentious and lacking in restraint.

Passions appear to be uncontrolled when the Greek symposium is situated in a barbarian context ${ }^{63}$. In his retort, Sparamizes questions the greatness involved in bringing a saddle-cloth to the king ${ }^{64}$. He implicitly doubts the merit of a form of restraint, in this case, applicable to a horse but symbolically relevant to the behaviour of Mithridates. The reader will recall at once the Platonic imagery of the soul in the Phaedrus as a chariot driven by a team of winged horses $(246 a)^{65}$. Now it is the black, unrestrained steed, evidently representing the passionate part of the human soul ${ }^{66}$, that drags down its driver ${ }^{67}$, far away from the plain of Truth and from beholding the true being $(248 \mathrm{bc})^{68}$. The soul then sheds its wings and plummets to earth, only to be incarnated in a

${ }^{60}$ Anacr., Fr. 11b Page = PMG 356; Hdt. 6.84; P1., Lg. 1.637e; Arist., Pr. 3.7.872a3-9; Athen. 10.427a-c; 11.499f. Cf. F. Hartog, 1988, pp. 169-70; M. C. Miller, 1991, p. 68.

${ }^{61}$ This sentiment may provide a clue for the occasional appearances of symposiasts in typically oriental dress, including the tiara cap, found painted on vases. Cf. F. Lissarrague, 1990, pp.11-3, who argues that these images signify the search for otherness experienced in the symposium, an escape from social restrictions. For other interpretations, which suggest that the figures represent foreign guests at dinner parties or else wealthy Athenians aping Eastern ways and dress, see K. De Vries, 1973, p.39 and M. C. Miller, 1991, pp. 69-71.

${ }^{62}$ E. Hall, 1989, pp. 79-84, 101 sqq.; E. Almagor, 2005, pp. 50-2. In Plutarch's writing, the barbarians are known for their lack of temperance. They engage in acts of savagery and cruelty (A. G. Nikolaidis, 1986, pp. 241-2; T. S. Sснмidt, 1999, pp. 27-67), indulge in luxury (A. G. Nikolaidis, 1986, pp. 237-8; T. S. Sснмidт, 1999, pp. 107-139), are generally untrustworthy (T. S. Schмidt, 1999, pp. 203-12) and hold superstitious beliefs (A. G. Nikolaidis, 1986, pp. 234-35; T. S. Sснміdт, 1999, pp. 224-34), to name but a few their negative traits.

${ }^{63}$ Cf. Hdt. 5.18-20. Compared with these depictions, Xenophon's descriptions in the Cyropaedia of the Persian banquets as devoid of drunkenness (cf. C. J. Tuplin, 1990, p. 26; D. L. GERA, 1993, pp. 150-1) would seem a literary idealization.

${ }^{64}$ Vide supra n. 54.

${ }^{65}$ Cf. Ant. 36.2. Cf. C. B. R. Pelling, 1988, p. 217; T. Duff, 1999, pp. 78-9, 85. Cf. M. B. TRAPP, 1990 on the popularity of this image in second century AD literature.

${ }^{66}$ On the exact nature of this correspondence see R. Hackforth, 1952, p. 72; C. J. Rowe, Plato. Phaedrus, with Translation and Commentary, Warminster, 1986 ad loc. 246b1-3; cf. D. A. White, 1993, pp. 89-93; E. Belfiore, 2006.

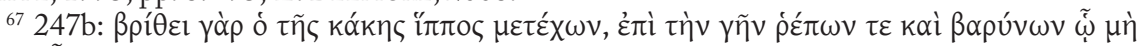

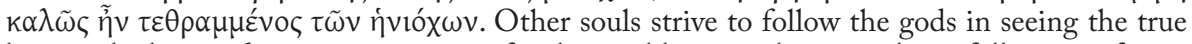
being, which provides pasturage proper for their noblest part, but none has a full vision of it.

${ }^{68}$ Cf. Plu., De def. orac. $422 \mathrm{~b}$. 
mortal body and embedded in the cycle of births ${ }^{69}$. While basing his account on Ctesias' description, Plutarch seems to skillfully combine this imagery of passion as an unbridled horse, deviation from truth, and a general movement downward, manifested in the action of the banquet participants, whose eyes are cast earthward ${ }^{70}$.

At the end of the dinner scene, the host, assuming one of the key functions of a symposiarch ${ }^{71}$, tones down emotions by urging the participants to keep their differences within bounds as they eat and drink, and to prostrate themselves before the king's daimon ${ }^{72}$. Here a play of stereotypes is manifest, since it is one thing, a very Greek thing, to be a calming symposiarch but quite another to do so by recommending this most non-Greek of actions. This play has a bearing on the character of the monarch. The appeal to this deity seems to fulfill a restrictive role; it is now expected of the king to restrain the passions so recklessly exhibited during the feast ${ }^{73}$. But instead of curbing passions with a measure of self-control as he has done on previous occasions, Artaxerxes stifles them in another manner.

It would seem that the insertion of the potentially disorderly Greek symposium into barbarian circumstances, inherently devoid of the Hellenic rules and codes for self-control - which consist of trust, cooperation and equality produces a new situation. The king chooses to react with unprecedented cruelty to the misbehaviour of Mithridates and to suppress passion with even greater passion. Since this unbridled conduct is directly linked with the loosening of control begun at the banquet and caused by it, the symposium appears not so much as revealing the king's true character but as totally altering it from its previous portrayal.

At this juncture in the narrative, the reader is not sure as to the correct interpretation of the ethos of Artaxerxes ${ }^{74}$. One possibility is that his inner

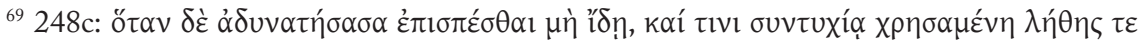

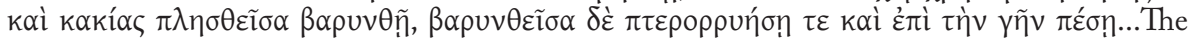
souls are incarnated in several types of men, ranging from the philosopher to the tyrant, in accordance with the measure of the truth seen by them (248d).

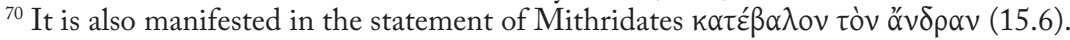

${ }^{71}$ See Quaest. conv. 1.4, 620a-622b. Cf. S.-T. Teodorsson, 1999, p. 61.

${ }_{72}$ A significant question is whether the host is the same person as Sparamizes, as both use the relatively uncommon phrase $\tilde{\omega} \tau \tilde{\alpha} v$ when addressing Mithridates $(15.4,15.7)$. Several scholars have already been baffled by this difficulty or have confounded the two. (Cf. F. E. BREnk, 1977, p. 151). W.W. TARn, 1928, p. 209, claims to have formerly equated the two and then changed his opinion after a conversation with A. D. Nock. Did Plutarch mean to confuse his readers? It should be noted that one of the characters aims to restrain passion while the other aspires to give vent to it. Attributing these two conflicting roles to the same figure may point to the two possible routes of action expected of the king with regard to the offence of Mithridates, and even to an innate inconsistency within the ethos of Artaxerxes, which is also displayed by the mention of the daimon and which constitutes a recurring motif in the biography to its very end (culminating in 29.11).

${ }^{73}$ I deal with the literary significance of the king's daimon in a forthcoming paper.

${ }^{74}$ Three scholars suggest different portrayals of the king. Orsi (in M. Manfredini \& Orsi, 1987 , pp. xxvii - xxviii) stresses a positive characterization emerging from the biography; D. C. Hood, 1967, pp. 68-85, on the other hand, emphasizes a negative image. T. S. SchmidT, 1999, p. 
savagery, so far concealed, has been finally unmasked. Another is that he has degenerated from a mild and philanthropos monarch to a cruel and harsh despot ${ }^{75}$. The banquet scene plays an important role in this uncertainty. For wine itself is an ambiguous beverage. Sweet and dangerous, it reveals as much as it distorts, making the real apparent and the apparent real. It discloses the truth as much as it leads to forgetfulness, generates civilized fellowship and philanthropia but at the same time may cause the lowest form of brutal behaviour. One would assume that what is needed is moderation, or finding the right measure, which Mithridates and Artaxerxes, being barbarians, are clearly shown to lack. Or is it so? Plutarch does not simply adopt ethnic stereotypes. He plays on them and exploits various familiar ethnic themes to create a complex interplay. The difficulty of interpreting what is happening in this "barbarian" symposium reflects how disconcerting it is when familiar features from the Greek banquet combine in a new and disorienting way. Eventually the evasiveness of the categories makes understanding of the situation a complicated matter for the reader, just as it proves to be for Mithridates.

\section{Works cited}

Almagor, E., "Who Is a Barbarian? The Barbarians in the Ethnological and Cultural Taxonomies of Strabo", in D. Dueck et AL. (eds.), Strabo's Cultural Geography, Cambridge, 2005.

Anderson, J. K., Xenophon, London, 1974.

Bassett, S. R., "The Death of Cyrus the Younger”, CQ, 49 (1999) 473-83.

318-24, in his research into the representation of barbarians in Plutarch's Lives, advances a more attractive and balanced approach by combining both views. He depicts Artaxerxes as better than other barbarians, including the minor characters in this biography, though he argues that his portrait reveals more negative traits. Perhaps the development of the presentation of Artaxerxes' character should also be considered in the evaluation of his personality; notice, then, should be taken of the story-line of this Life.

75 Plutarch was long seen as ascribing a static ethos to his heroes, thus making ostensible dramatic changes, such as cruelty, to be understood as the revelation of true character traits, which were concealed for various reasons (cf. Philip's case in Aratus, 49.1, another non-parallel Life). Nevertheless, this approach has been challenged by scholars who believe that Plutarch espoused a belief in the possibility of an altered character. See F. E. BREnK, 1977, pp. 176-81; S. Swain, 1989. Cf. De sera, 559bc. According to this modified view, Plutarch holds that a person confronted with great changes in circumstances, or vitiated by undeserved calamities, may lose his internal balance between the rational and irrational. Compare the notable case of Sertorius (Sert. 25.6). See D.A. Russell, 1966, p. 146; B. Bucher-Isler, 1972, pp. 79-80, for the opinion that Plutarch believes in the constant nature (physis) of a hero, i.e., his inborn qualities, as opposed to his changeable character. Cf. De tranq. an., 475d-476a. Yet cf. C. Gill, 2006, pp. 412-21, who advances the possibility of a collapse of character in Plutarch's Lives, consistent with the biographer's Platonic-Aristotelian view (cf. C. GiLl, 1983 for an earlier formulation of this idea, based on a conceptual contrast between 'character' and 'personality', on which cf. C. B. R. Pelling, 2002, pp. 283-329). 
Belfiore, E., "Dancing with Gods: The Myth of the Chariot in Plato's Phaedrus", AJPh, 127 (2006) 185-217.

Benardete, S., Herodotean Inquiries, The Hague, 1969.

Bigwood, J. M., “Ctesias'Account of the Revolt of Inarus”, Phoenix, 30 (1976) $1-25$.

“Ctesias as Historian of the Persian Wars", Phoenix, 32 (1978) 19-41.

"The Ancient Accounts of the Battle of Cunaxa", AJPh, 104 (1983) 34057.

Boyce, M., A History of Zoroastrianism, vol. 1, Leiden, Cologne, 1975.

A History of Zoroastrianism, vol. 2, Leiden/Cologne, 1982.

Brenk, F. E., In Mist Apparelled: Religious Themes in Plutarch's Moralia and Lives, Leiden, 1977.

Briant, P., From Cyrus to Alexander, Winona Lake, IN, 2002.

Bucher-Isler, B., Norm und Individualität in den Biographien Plutarchs, Bern, Stuttgart, 1972.

Burkert, W., "Oriental Symposia: Contrasts and Parallels", in W. J. Slater (ed.), 1991, pp.7-24.

Cole, T., "Archaic Truth”, QUCC, 42 (1983) 7-28.

Detienne, M. \& Vernant, J.-P. (eds.), Cunning Intelligence in Greek Culture and Society (trans. J. Lloyd), Hassocks, 1978.

Drews, R., The Greek Accounts of Eastern History, Cambridge, MA, 1973.

DuBois, P., Torture and Truth, New York, London, 1991.

Duff, T., Plutarch's Lives: Exploring Virtue and Vice, Oxford, 1999.

Gera, D. L., Xenophon's Cyropaedia: Style, Genre and Literary Technique, Oxford, 1993.

"Viragos, Eunuchs, Dogheads, and Parrots in Ctesias", in G. Herman \& I. Shatzman (eds.), Greeks between East and West: Essays in Greek Literature and History in Memory of David Asheri, Jerusalem, 2007.

Gill, C., "The Question of Character-Development: Plutarch and Tacitus", CQ, 33 (1983) 469-87.

The Structured Self in Hellenistic and Roman Thought, Oxford, New York, 2006.

Goossens, G., "Le sommaire des Persica de Ctésias par Photius", RBPH, 28 (1950) 513-21. 
Hackforth, R., Plato's Phaedrus, translated with introduction and commentary. Cambridge, 1952.

Hall, E., Inventing the Barbarian, Oxford, 1989.

Harrison, T. (ed.), Greeks and Barbarians, New York, 2002.

Hartog, F., The Mirror of Herodotus (trans. J. Lloyd), Berkeley/Los Angeles, London, 1988.

Henderson, W. J., "Aspects of the Ancient Greek Symposium”, Akroterion, 45 (2000) 6-26.

Hirzel, R., Plutarch, Leipzig, 1912.

Hood, D. C., Plutarch and the Persians, PhD diss. University of Southern Califonia, 1967.

Hug, A., "Symposion", RE, 4. A 1 (1931) 1266-70.

Huss, B., Xenophons Symposion: Ein Kommentar, Stuttgart, Leipzig, 1999.

Jacoby, F., "Ktesias”, RE, 11.2 (1922) 2032-73.

Kent, R.G., Old Persian: Grammar, Text, Lexicon, New Haven, 1953.

Kromayer, J., "Kunaxa”, in J. Kromayer \& G. Veith (eds.), Antike Schlachtfelder, Berlin, (1924-1931), pp. 222-42.

Lenfant, D., Cetsias de Cinidos, Paris, 2004.

Lincoln, B., Religion, Empire and Torture: The Case of Achaemenian Persia, with a Postscript on Abu Ghraib, Chicago, 2007.

Lissar rague, F., The Aesthetics of the Greek Banquet: Images of Wine and Ritual (trans. A. Szegedy Maszak), Princeton, 1990.

Lommel, H., Die Religion Zarathustras nach dem Awesta dargestellt, Tübingen, 1930.

Manfredini, M. \& Orsi, D. P., Plutarcho, Le Vite di Arato et di Artaserse, Rome, 1987.

Martin JR., H. M., "The Concept of Philanthropia in Plutarch's Lives", AJPh, 82 (1961) 164-75.

Miller, M. C., "Foreigners at the Symposium?”, in W. J. Slater (ed.), 1991, pp. 59-81.

Momigliano, A., "Tradizione e invenzione in Ctesia", Atena e Roma, n.s. 12 (1931) 15-44.

Montes Cala, J. G. et al. (eds.), Plutarco, Dioniso y El Vino. Actas del VI Simposio Español Sobre Plutarco (Cádiz, 14-16 de Mayo, 1998), Madrid, 1999. 
Murray, O., "Symposium and Männerbund", in P. Oliva \& A. Frolikova (eds.), Concilium Eirene, Prague, 1982.

"The Symposium as a Social Organization", in R. HAGg (ed.), The Greek Renaissance of the Eighth Century BC: Tradition and Innovation. Stockholm, 1983. (ed.), Sympotica. A Symposium on the Symposium, Oxford, 1990. \& Tecuşan, M. (eds.), In Vino Veritas, London, 1995.

Nikolaidis, A. G., "Hellenikos-Barbarikos: Plutarch on Greek and Barbarian Characteristics", WS, 20 (1986) 229-44.

"Plutarch's Attitude to Wine", in J. G. Montes Cala et al. (eds.), 1999, pp. 337-48.

Nippel, W., “The construction of the 'Other"'(trans. A. Nevill), in T.Harrison (ed.), 2002, pp. 278-310.

Oranje, H., Euripides' Bacchae: The Play and Its Audience, Leiden, 1984.

Paul, G., "Symposia and Deipna in Plutarch's Lives and in Other Historical Writings", in W. J. Slater (ed.), 1991, pp. 157-69.

Pelling, C. B. R., Plutarch: Life of Antony, Cambridge, 1988.

Plutarch and History, London, 2002.

Rahe, P. A., "The Military Situation in Western Asia on the Eve of Cunaxa”, AJPh, 101 (1980) 79-96.

De Romilly, J., La douceur dans la pensée grecque, Paris, 1979.

Rösler, W., "Wine and Truth in the Greek Symposion", in O. Murray \& Tecuşan (eds.), 1995, pp. 106-12.

Russell, D. A., “On Reading Plutach's Lives”, Gछ'R, 13 (1966) 139-54.

Sancisi-Weerdenburg, H., "Decadence in the Empire or Decadence in the Sources? From Source to Synthesis: Ctesias", AcbHist 1 (1987) 33-46.

Schmidt, T. S., Plutarque et les Barbares: la rhétorique d'une image, Louvain, 1999.

Shahbazi, A. S., "An Achaemenid Symbol I. A Farewell to 'Fravahr and Ahuramazda", AMI, 7 (1974) 135-44.

"An Achaemenid Symbol II. Farnah '(God given) Fortune' Symbolised", AMI, 13 (1974) 119-47.

Shipley, D. R., A Commentary on Plutarch's Life of Agesilaos, Oxford, 1997.

Slater, W. J., "Peace, Symposium, and the Poet", ICS, 6 (1981) 205-14.

"Sympotic Ethics in the Odyssey", in O. Murray (ed.), 1990, pp. 
213-20.

(ed.), Dining in a Classical Context, Ann Arbor, 1991.

Snell, B., "Aletheia", Würzburger Jahrbucher für die Altertumswissenschaft, 1 (1975) 9-17.

Stausberg, M., Die Religion Zarathushtras. vol. I \& II, Stuttgart, 2002.

Stevenson, R. B., Persica, Edinburgh, 1997.

Swain, S., "Character Change in Plutarch", Phoenix, 43 (1989) 62-8.

Tarn, W. W., “The Hellenistic Ruler-Cult and the Daemon”, JHS, 48 (1928) 206-19.

Tavadia, J. C., "Sūr Saxvan: A Dinner Speech in Middle Persian", JCOI, 29 (1935) 1-99.

Taylor, L. R., "The 'Proskynesis and the Hellenistic Ruler Cult", JHS, 47 (1927) 53- 62.

Teodorsson, S.-T., A Commentary on Plutarch's Table Talks, vol. I, Göteborg. 1989. A Commentary on Plutarch's Table Talks, vol. III, Göteborg. 1996.

"Dionysus Moderated and Calmed: Plutarch on the Convivial Wine", in J. G. Montes Cala et al. (eds.), 1999, pp. 57-69.

Titchener, F. B., "Everything to Do with Dionysus: Banquets in Plutarch's Lives", in J. G. Montes Cala et Al. (eds.), 1999, pp. 491-99.

Tolles, D., The Banquet Libations of the Greeks, Ann Arbor, 1943.

Trapp, M. B., "Plato's Phaedrus in Second-Century Greek Literature”, in D. A. Russell (ed.), Antonine Literature, Oxford, 1990, pp. 141-73.

Tuplin, C. J., "Persian decor in Cyropaedia: some observations", AchHist, 5 (1990) 17-29.

Vickers, M. J., Greek Symposia, London, 1984.

De Vries, K., "East Meets West at Dinner”, Expedition, 15 (1973) 32-9.

White, D. A., Rhetoric and Reality in Plato's Phaedrus, Albany, NY, 1993.

Wylie, G., "Cunaxa and Xenophon”, AClass, 61 (1992) 119-34. 